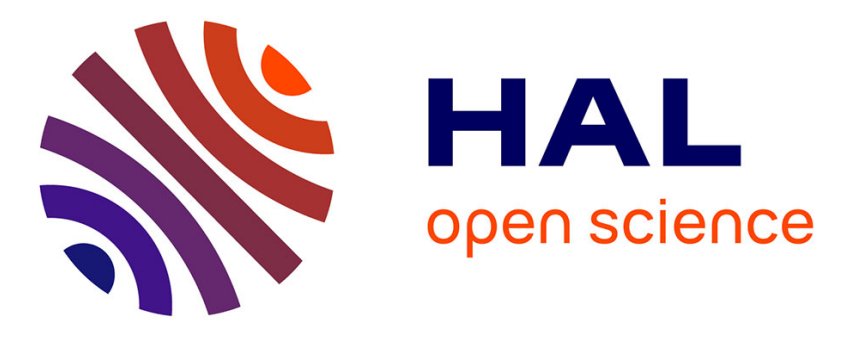

\title{
Nodular diagnosis for integrated improvement of symbiotic nitrogen fixation in cropping systems
}

Jean-Jacques Drevon, S. Gugliemni, G. Boyer, E. Lafosse-Bernard, Raphael Metral, Catherine Pernot, H. Vailhe

\section{- To cite this version:}

Jean-Jacques Drevon, S. Gugliemni, G. Boyer, E. Lafosse-Bernard, Raphael Metral, et al.. Nodular diagnosis for integrated improvement of symbiotic nitrogen fixation in cropping systems. Biological Nitrogen Fixation: Towards Poverty Alleviation through Sustainable Agriculture, 42, Springer Science + Business Media B.V., 385 p., 2008, 978-1-4020-8251-1. 10.1007/978-1-4020-8252-8_15. hal-02815703

\section{HAL Id: hal-02815703 https://hal.inrae.fr/hal-02815703}

Submitted on 6 Jun 2020

HAL is a multi-disciplinary open access archive for the deposit and dissemination of scientific research documents, whether they are published or not. The documents may come from teaching and research institutions in France or abroad, or from public or private research centers.
L'archive ouverte pluridisciplinaire HAL, est destinée au dépôt et à la diffusion de documents scientifiques de niveau recherche, publiés ou non, émanant des établissements d'enseignement et de recherche français ou étrangers, des laboratoires publics ou privés. 


\section{黑 Springer Link}

\section{Eind quthihewte Access preview-only content}

Biological Nitrogen Fixation: Towards Poverty Alleviation through Sustainable Agriculture

Current Plant Science and Biotechnology in Agriculture Volume 42, 2008, pp 51-55

\section{Nodular Diagnosis for Integrated Improvement of Symbiotic Nitrogen Fixation in Cropping Systems}

Nodular diagnosis consists of measuring the nodulation of a legume in an area of production, and relating it to the growth and subsequent yield of the legume (Drevon, 2001; Drevon et al., 2001; 2003). The objective of this procedure is to respond to the following questions: (i) does symbiotic nitrogen fixation (SNF) cover the $\mathrm{N}$ requirement of the legume in the cropping system? and (ii) what are the environmental factors limiting SNF in the area?

Page \%P

Page 1 


\title{
NODULAR DIAGNOSIS FOR INTEGRATED IMPROVEMENT OF SYMBIOTIC NITROGEN FIXATION IN CROPPING SYSTEMS
}

\author{
J. J. Drevon', S. Gugliemni ${ }^{2}$, G. Boyer ${ }^{3}$, E. Lafosse-Bernard ${ }^{4}$, R. Métral ${ }^{2}$, \\ C. Pernot ${ }^{1}$ and $\mathrm{H}$. Vailhe ${ }^{1}$ \\ ${ }^{1}$ INRA-Montpellier-Supagro, France; ${ }^{2} \mathrm{CT}$ Montpellier-Supagro, France; \\ ${ }^{3}$ Chambre d'Agriculture, Catelnaudary, France; ${ }^{4} \mathrm{CIVAM}-\mathrm{Bio}$, Montpellier, \\ France
}

Nodular diagnosis consists of measuring the nodulation of a legume in an area of production, and relating it to the growth and subsequent yield of the legume (Drevon, 2001; Drevon et al., 2001; 2003). The objective of this procedure is to respond to the following questions: (i) does symbiotic nitrogen fixation (SNF) cover the $\mathrm{N}$ requirement of the legume in the cropping system? and (ii) what are the environmental factors limiting SNF in the area?

The nodular diagnosis is based on sampling a site chosen from the fields of the bean farmers who agreed to participate in the agronomic survey on the nodulation of their plants. Each site was divided into two parts, one without $\mathrm{N}$ fertilization and the other receiving a non-limiting $\mathrm{N}$ fertilizer with the aim of establishing whether the $\mathrm{N}$ nutrition is indeed the major factor limiting the legume growth in that area. Once this was established, two practices (local practice versus an alternative) were assessed in an agronomic trial within the area. Thus, the sites of nodular diagnosis were multi-locational, so that tests could be shared with many extension agents. However, it was decided not to test more than one alternative bio-technique with farmers. A reliable number of sites for use was determined to be ten per area. At flowering, corresponding to the stage when the SNF potential starts to decline, 20 plants were dug out (20-cm depth) at four sampling points within a homogeneous site. Plants with roots and nodules were preserved in a cold room for subsequent measurement of their individual biomass of shoots and nodules.

\section{Spatial Variation in Nodulation and Efficiency in Use of the Rhizobial Symbiosis}

Figure 1 illustrates the variation in nodule number, from less than 5 up to more than 50 , which was generally observed at each site with instances of the total absence of nodules on some or all plants surveyed in fields of common bean in rotation with wheat in Lauragais farming systems. 
No Body Text -- translate me!
Page 2

No Bod
Page 2

$$
\text { \# }
$$


A simple regression was obtained from plots of the nodulation parameter (number or biomass) and the growth of plants as shown in Figure 1. This allowed for calculation of the ratio of additional shoot growth for each additional nodule, i.e., the slope of the regression was considered as an assessment of the efficiency of use of the rhizobial symbiosis (EURS) at that site. This EURS varied significantly between sites.

\section{$\mathrm{gsDW} / \mathrm{pl}(\mathrm{R6} 6-7)$}
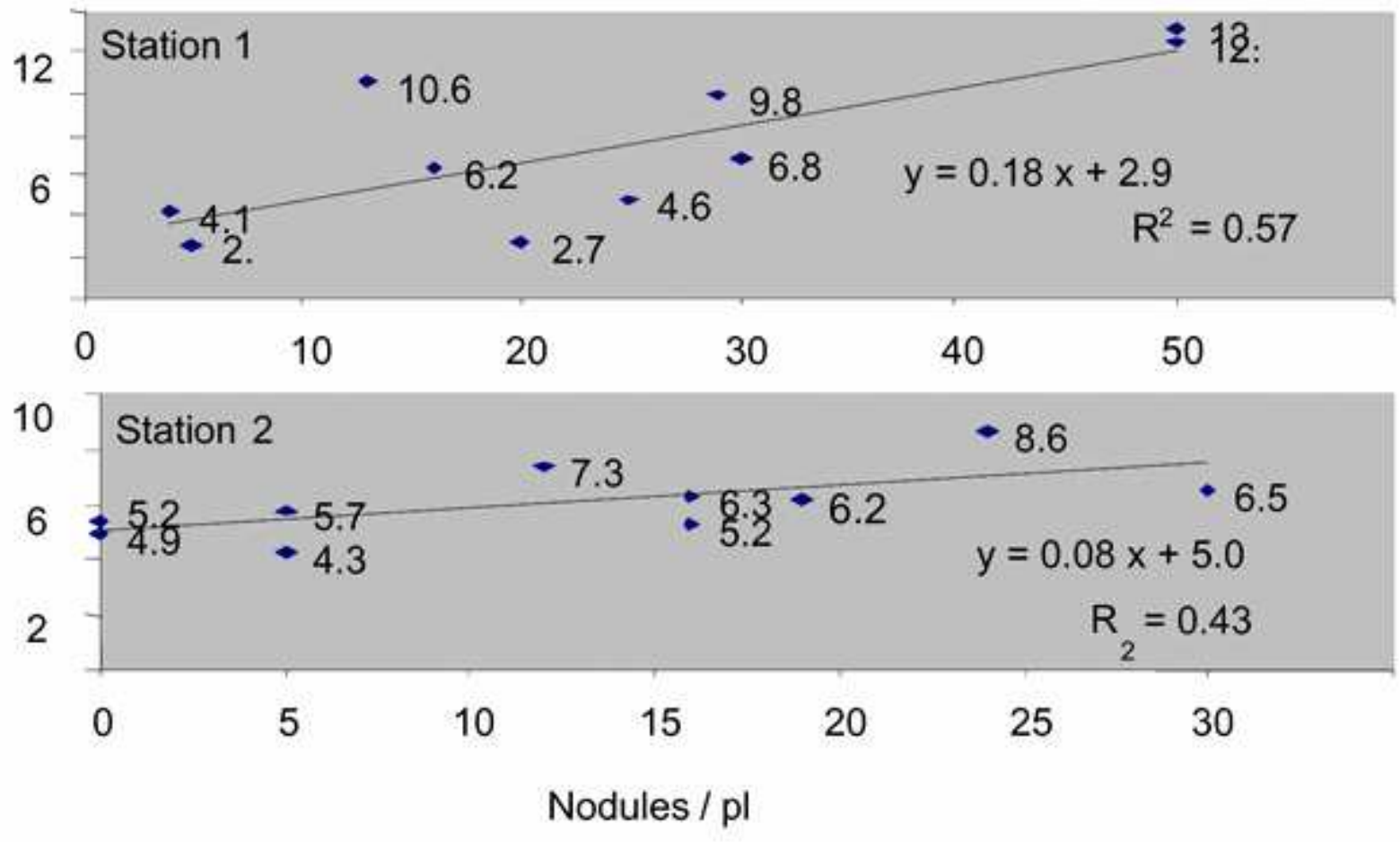

Figure 1. Efficiency in utilisation of the rhizobial symbiosis varies among fields in Lauragais.

The comparison of growth and yield of common bean with or without an optimal $\mathrm{N}$ fertilization within each site (Figure 2) made it possible to assess whether the nodulation or the shoot is the determining variable of the regression. As observed in site 5 and 6, the higher growth with $\mathrm{N}$ fertilization established that the low nodulation at those sites was the major factor that limited bean yield. These were fields where improving SNF could directly contribute to yield improvement. This may be obtained by inoculation with a native rhizobia isolated from sites with high EURS. This was not the case with sites 1 and 2 where it was found that SNF could complement soil $\mathrm{N}$ efficiently to support such a high bean grain yield of $3 \mathrm{t} \mathrm{ha}^{-1}$. However, exceptionally higher grain yield than $4 \mathrm{t} \mathrm{ha}^{-1}$ were found at site 3 , although the EURS was relatively high in the non-fertilized part of the site. This result suggested that the plant genotype did not have an effective capacity for SNF. This prompted the farmers to request genetic improvement of the lingot type beans, including (among other selection parameters) the height of the pods in order to decrease the losses at harvest. 
No Body Text -- translate me!

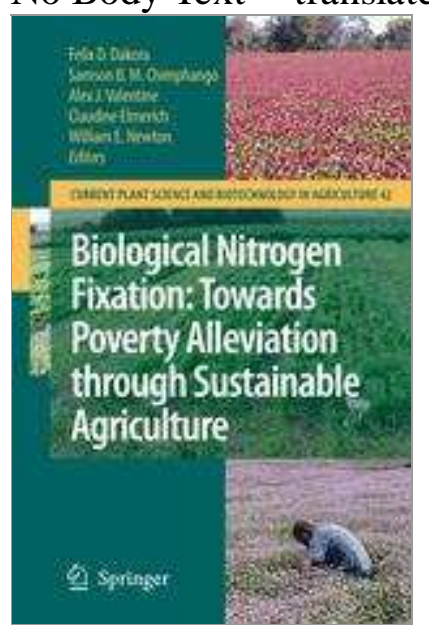




\section{Related Content}

\section{About this Chapter}

Title

Nodular Diagnosis for Integrated Improvement of Symbiotic Nitrogen Fixation in Cropping Systems

Book Title

Biological Nitrogen Fixation: Towards Poverty Alleviation through Sustainable Agriculture

Book Subtitle

Proceedings of the 15th International Nitrogen Fixation Congress and the 12th International

Conference of the African Association for Biological Nitrogen Fixation

Book Part

I

Pages

pp 51-55

Copyright

2008

DOI

Print ISBN

10.1007/978-1-4020-8252-8_15

978-1-4020-8251-1

Online ISBN

978-1-4020-8252-8

Series Title

Current Plant Science and Biotechnology in Agriculture

Series Volume

42

Series ISSN

0924-1949

Publisher

Springer Netherlands

Copyright Holder

Springer Science + Business Media B.V.

Additional Links

- About this Book

Topics

- Microbiology

- Agriculture

- Microbial Genetics and Genomics

- Plant Biochemistry

- Microbial Ecology

Industry Sectors

- Biotechnology

- Oil, Gas \& Geosciences 
- Health \& Hospitals

- Chemical Manufacturing

- Consumer Packaged Goods

- Pharma

Editors

- Felix D. Dakora ${ }^{(1)}$

- Samson B. M. Chimphango (2)

- Alex J. Valentine (3)

- Claudine Elmerich ${ }^{(4)}$

- William E. Newton ${ }^{(5)}$

Editor Affiliations

- 1. Cape Town Peninsula, University of Technology

- 2. University of Cape Town

- 3. University of the Western Cape

- 4. Institut Pasteur

- 5. Virginia Polytechnic Institute and State University

Authors

- J. J. Drevon ${ }^{(6)}$

- S. Gugliemni (7)

- G. Boyer $^{(8)}$

- E. Lafosse-Bernard ${ }^{(9)}$

- R. Métral (7)

- C. Pernot ${ }^{(6)}$

- H. Vailhe ${ }^{(6)}$

Author Affiliations

- 6. INRA-Montpellier-Supagro, France

- 7. CT Montpellier-Supagro, France

- 8. Chambre d'Agriculture, Catelnaudary, France

- 9. CIVAM-Bio, Montpellier, France

Confirm download

The cost of downloading this content will be charged to your organisation. 
If you have a cost code, please enter it:

What is this?

6801002 scientific documents at your fingertips

(C) Springer, Part of Springer Science+Business Media

You have been redirected to our new and improved site.

More info I'm good, don't tell me again

.springer.com 
BIOLOGICAL NITROGEN FIXATION: TOWARDS POVERTY ALLEVIATION THROUGH SUSTAINABLE AGRICULTURE 


\section{Current Plant Science and Biotechnology in Agriculture}

VOLUME 42

Scientific Advisory Board

J. Hamblin, Research Director, Export Grains Centre Ltd., WA, Australia

H.-J. Jacobsen, Universität Hannover, Hannover, Germany

\section{Aims and Scope}

The book series is intended for readers ranging from advanced students to senior research scientists and corporate directors interested in acquiring in-depth, state-of-the-art knowledge about research findings and techniques related to all aspects of agricultural biotechnology. Although the previous volumes in the series dealt with plant science and biotechnology, the aim is now to also include volumes dealing with animals science, food science and microbiology. While the subject matter will relate more particularly to agricultural applications, timely topics in basic science and biotechnology will also be explored. Some volumes will report progress in rapidly advancing disciplines through proceedings of symposia and workshops while others will detail fundamental information of an enduring nature that will be referenced repeatedly.

For other titles published in this series, go to www.springer.com/series/6444 


\section{Biological Nitrogen Fixation: Towards Poverty Alleviation through Sustainable Agriculture}

Proceedings of the 15th International Nitrogen Fixation Congress and the 12th International Conference of the African Association for Biological Nitrogen Fixation

Edited by

Felix D. Dakora

Cape Town Peninsula University of Technology,

Cape Town, South Africa

Samson B. M. Chimphango

University of Cape Town, Rondebosch, South Africa

Alex J. Valentine

University of the Western Cape, South Africa

Claudine Elmerich

Institut Pasteur, Paris, France

and

William E. Newton

Virginia Polytechnic Institute and State University, Blacksburg, VA, USA 


\section{Editors}

Felix D. Dakora

Cape Town Peninsula

University of Technology

Cape Town, South Africa

Alex J. Valentine

University of the Western Cape

South Africa

William E. Newton

Virginia Polytechnic Institute

and State University

Blacksburg, VA, USA
Samson B. M. Chimphango

University of Cape Town

Rondebosch, South Africa

Claudine Elmerich

Institut Pasteur

Paris, France

ISBN: 978-1-4020-8251-1

e-ISBN: 978-1-4020-8252-8

Library of Congress Control Number: 2008930755

(C) 2008 Springer Science + Business Media B.V.

No part of this work may be reproduced, stored in a retrieval system, or transmitted in any form or by any means, electronic, mechanical, photocopying, microfilming, recording or otherwise, without written permission from the Publisher, with the exception of any material supplied specifically for the purpose of being entered and executed on a computer system, for exclusive use by the purchaser of the work.

Cover Illustration: A field trial with lentil showing the response to inoculation, and fields of clover in bloom. Photographs courtesy of John Howieson, Murdoch University, Western Australia and reproduced with permission.

Printed on acid-free paper

987654321

springer.com 


\title{
15th INTERNATIONAL NITROGEN FIXATION CONGRESS
}

\author{
was supported by \\ Cape Peninsula University of Technology \\ UNESCO \\ CTA \\ (Technical Centre for Agricultural and Rural Cooperation, \\ operating within the Cotonou Agreement between the \\ African, Caribbean and Pacific Group and the European Union) \\ National Research Foundation, Pretoria
}

Department of Science and Technology, Pretoria

PlantBio (South Africa)

Academy of Sciences of South Africa

South African Airlines
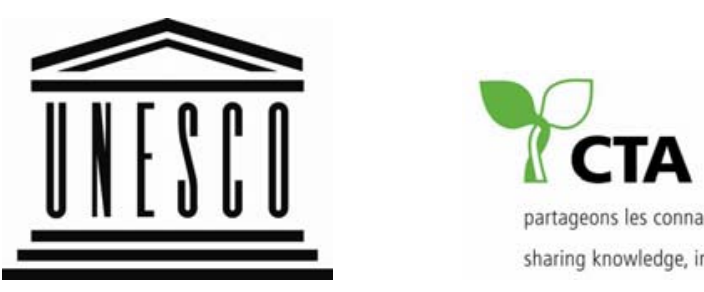

partageons les connaissances au profit des communautés rurales sharing knowledge, improving rural livelihoods 


\section{5th INTERNATIONAL NITROGEN FIXATION CONGRESS}

was organized by the following committees

\section{Local Organizing Committee}

F. D. Dakora, Cape Peninsula University of Technology, South Africa

S. B. M. Chimphango, University of Cape Town, South Africa

P. Ndakidemi, Cape Peninsula University of Technology, South Africa

A. J. Valentine, University of the Western Cape, South Africa

N. Brewin, John Innes Centre, England, UK

E. Danckwerts, A \& E Consultants, South Africa

\section{Africa Regional Organizing Committee}

I. Ndoye (Senegal)

M. Gueye (Senegal)

S. Sylla (Senegal)

S. Mpepereki (Zimbabwe)

N. Karanja (Kenya)

I. Yattara (Mali)

L. Thiombiano (FAO, Ghana)
S. K. A. Danso (Ghana)

D. Lesueur (Kenya)

M. Neyra (Senegal)

R. Abaidoo (IITA, Nigeria)

A. Beki (Algeria)

D. Odee (Kenya)

M. M. Spencer (Senegal)

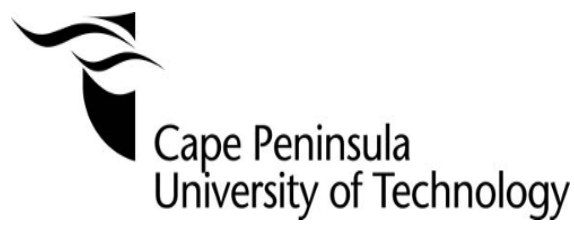




\title{
15th INTERNATIONAL NITROGEN FIXATION CONGRESS
}

\section{International Steering Committee}

\author{
W. E. Newton (USA) \\ C. Elmerich (France) \\ T. Finan (Canada) \\ H. Hennecke (Switzerland)
}

F. O. Pedrosa (Brazil)

A. Pühler (Germany)

I. Tikhonovich (Russia)

Y.-P. Wang (China)

\section{International Program Advisory Committee}

\author{
N. Boonkerd (Thailand) \\ W. Broughton (Switzerland) \\ M. Buck (UK) \\ E. C. Cocking (UK) \\ H. Das (India) \\ F. de Bruijn (France) \\ R. Dixon (UK) \\ Z. M. Dong (Canada) \\ D. Emerich (USA) \\ R. Fani (Italy) \\ P. Gresshoff (Australia) \\ R. Haselkorn (USA) \\ R. Holm (USA) \\ C. Kennedy (USA) \\ A. Kolb (France) \\ J. K. Ladha (The Philippines) \\ P. Ludden (USA) \\ K. A. Malik (Pakistan)
}
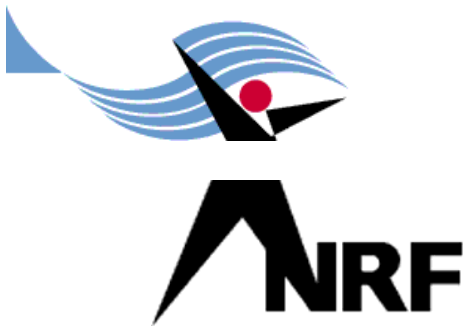

E. Martinez-Romero (Mexico)

K. Minamisawa (Japan)

M. O'Brien (USA)

F. O'Gara (Ireland)

K. Pawlowski (Sweden)

B. Rolfe (Australia)

M. Rahman (Bangladesh)

C. Ronson (New Zealand)

T. Ruiz-Argueso (Spain)

S.-J. Shen (China)

H. P. Spaink (The Netherlands)

G. Stacey (USA)

S. Tabata (Japan)

N.-T. Hein (Vietnam)

R. Thorneley (UK)

C. Vance (USA)

D. Werner (Germany) 


\section{Contents}

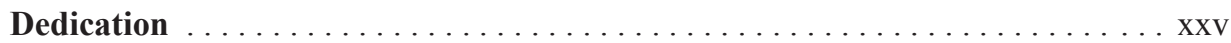

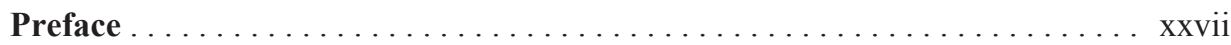

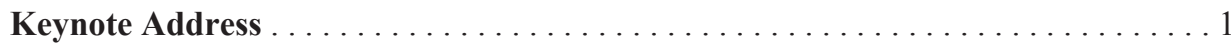

Gene discovery and marker development in crop legumes

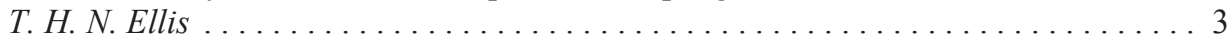

\section{Section 1. Towards Sustainable Agriculture}

A. Crop Improvement and Sustainable Agriculture for Poverty Alleviation ... . 9

Nutrient mining or carbon sequestration? BNF inputs can make the difference R. M. Boddey, C. P. Jantalia, L. Zotarelli, A. Okito, B. J. R. Alves,

S. Urquiaga and T. J. C. Amado .................................11

Tripartite symbiotic system of pea (Pisum sativum L.): Applications in sustainable agriculture A. Y. Borisov, T. N. Danilova, O. Y. Shtark, I. I. Solovov, A. E. Kazakov, T. S. Naumkina, A. G. Vasilchikov, V. K. Chebotar and I. A. Tikhonovich ....... . 15

Plant growth-promoting diazotrophs: Optimising their role as key agents in achieving more efficient nutrient use by field crops

I. R. Kennedy, M. Kecskés, R. Deaker, R. J. Roughley, S. Marsh, M. Rose,

A. Choudhury, N. T. Hien, P. T. Cong, P. Van Toan and T. T. Be ...

Multi-factor approach to identifying cowpea genotypes with superior symbiotic traits and higher yield for Africa

S. B. M. Chimphango, A. Belane, J. B. Naab, P. B. Tanzubil, J. A. N. Asiwe,

P. A. Ndakidemi, R. P. D. van Heerden and F. D. Dakora ............... 23

BNF applications for poverty alleviation

G. W. O'Hara, J. G. Howieson, R. J. Yates, D. Real and C. Revell ............ . 25

Biological nitrogen fixation in resource-poor agriculture in South Africa

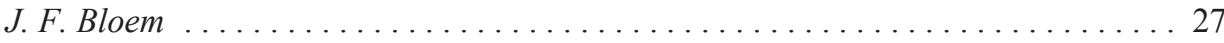

Combating food insecurity on sandy soils in Zimbabwe: The legume dilemma F. Mtambanengwe and P. Mapfumo ............................. 29 
Nitrogen fixation in agriculture: Forage legumes in Sweden as an example K. Huss-Danell, G. Carlsson, E. Chaia and C. Palmborg . . . . . . . . . . . . . 3

Biological nitrogen fixation with the soybean and common bean crops in the tropics M. Hungria, R. J. Campo, F. G. Barcellos, L. M. O. Chueire, P. Menna, J. S. Batista, F. G. S. Pinto, D. R. Binde, L. P. Godoy and A. A. Pereira

Biodiversity in Amazonian Dark Earth: A contribution for the sustainability of tropical soils from the microbial symbioses S. M. Tsai, B. O'Neill, F. Cannavan, D. Campos, R. Medau, S. Fedrizzi,

Techniques for the quantification of plant-associated biological nitrogen fixation R. M. Boddey, C. P. Jantalia, L. Zotarelli, A. Okito, B. J. R. Alves and S. Urquiaga.

Measuring $\mathrm{N}_{2}$ fixation in legumes using ${ }^{15} \mathrm{~N}$ natural abundance:

Some methodological problems associated with choice of reference plants

F. D. Dakora, A. C. Spriggs, P. A. Ndakidemi and A. Belane

How to quantify biological nitrogen fixation in forage legumes in the field

G. Carlsson and K. Huss-Danell . . .

B. Use of Inoculants

Nodular diagnosis for integrated improvement of symbiotic nitrogen fixation in cropping systems

J. J. Drevon, S. Gugliemni, G. Boyer, E. Lafosse-Bernard, R. Métral,

C. Pernot and H. Vailhe.

Evaluation of seed and liquid inoculation on biological nitrogen fixation and grain yield of soybean

A. D. C. Chilimba

Initiation, localization, and growth of nodules within the root system of pea as affected by assimilate availability A.-S. Voisin, N. G. Munier-Jolain, L. Pagès and C. Salon . .

Enhanced early nodulation of Medicago truncatula co-inoculated with Sinorhizobium medicae and Achromobacter xylosoxidans S. Fox, G. W. O'Hara, L. Brau, J. Howieson and W. Reeve. 
Gene transfer in the environment promotes the rapid evolution of a diversity of suboptimal and competitive rhizobia for Biserrula pelecinus L.

K. G. Nandasena, G. W. O’Hara, R. P. Tiwari and J. G. Howieson . . . . . . . . . 63

Effect of a genetically modified Rhizobium leguminosarum strain on bacterial and fungal diversity in the rhizosphere of Pisum sativum

C. Lantin, B. Bulawa, A. Haselier, R. Defez and U. B. Priefer . . . . . . . . . . 65

Inoculants for sugar cane: The scientific bases for the adoption of the technology for biofuel production

V. M. Reis, A. L. M. de Oliveira, M. F. da Silva, F. L. Olivares, J. I. Baldani, R. M. Boddey and S. Urquiaga . . . . . . . . . . . . . . 67

Detection and enumeration of plant growth-promoting bacteria M. L. Kecskés, E. Michel, B. Lauby, M. Rakotondrainibe,

A. Palágyi and I. R. Kennedy . . . . . . . . . . . . . . . . . . . . . . . . . . 69

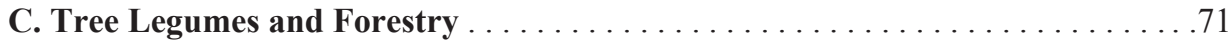

Nodulated tree legumes and their symbiotic Bradyrhizobium

in African and South-American tropical rainforests

Y. Prin, B. Dreyfus, C. Le Roux, G. Bena, M. Diabaté, P. de Lajudie,

A. Bâ, S. M. de Faria, A. Munive and A. Galiana . . . . . . . . . . . . . . . . . .73

Innovative microbial approaches to the management of Acacia senegal trees to improve and sustain gum-arabic production in sub-saharan Africa

D. Lesueur, A. Faye, S. Sall, J.-L. Chotte and A. Sarr . . . . . . . . . . . . . . 77

Acacia species used for revegetation in south-eastern Australia require more than one multi-strain rhizobial inoculant A. McInnes and J. Brockwell . . . . . . . . . . . . . . . . . . . . . . . . . . . . . .79

Management of symbionts in calliandra (Calliandra calothyrsus Meisn., Leguminosae) based agroforestry systems to improve growth, productivity, quality of fodder, and biological $\mathrm{N}_{2}$ fixation D. W. Odee, D. Lesueur, X. Poshiwa, D. Walters and J. Wilson . . . . . . . . . . . 81

Legume trees in the coffee agroecosystem of Puerto Rico M. A. Arango, M. Santana, L. Cruz and E. C. Schröder . . . . . . . . . . . . . . . . 83

Nodulation adapted to habitat submergence M. Holsters, W. Capoen, J. D. Herder, D. Vereecke, G. Oldroyd

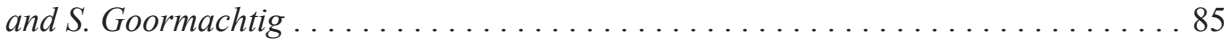


Mechanism of quick and reversible inhibition of soybean nodule growth and nitrogen fixation activity by nitrate and its metabolites

T. Ohyama, A. Yamazaki, N. Yamashita, T. Kimura, S. Ito,

N. Ohtake and K. Sueyoshi .

Inhibition of symbiotic nitrogen fixation by dark chilling in soybean

P. D. R. van Heerden, U. Schlüter, P. W. Mokwala, K. Kunert and C. H. Foyer . . . . 91

Do nodule phosphatase and phytase link with the phosphorus use

efficiency for $\mathrm{N}_{2}$-dependent growth in Phaseolus vulgaris?

J. J. Drevon, S. Kouas, L. Amenc, N. Alkama, S. Beebe, L. Bouhmana,

A. Lopez, C. Plassard, P. Rodino and G. Viennois . . . . . . . . . . . . . . . . . 93

The alternative sigma factor $\mathrm{rpoH} 2$ is required for salt tolerance

in Sinorhizobium sp. strain BL3

P. Tittabutr, W. Payakapong, N. Teaumroong, N. Boonkerd,

P. W. Singleton and D. Borthakur...

Root-nodule bacteria of arid-zone legumes for use in rehabilitation

in the Shark Bay World Heritage Area

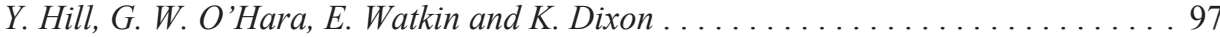

Effect of vegetation clearing on the nitrogen cycle

and water resource quality in South Africa

F. Rusinga, S. Israel and G. Tredoux . . . . . . . . . . . . . . . . . . . . . . . 99

Biorhizoremediation of heavy metals toxicity using

Rhizobium-legume symbioses

E. Pajuelo, M. Dary, A. J. Palomares, I. D. Rodriguez-Llorente,

J. A. Carrasco and M. A. Chamber . . . . . . . . . . . . . . . . . . . . . . . . . 101

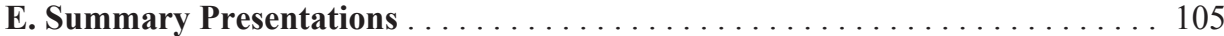

The commercialisation of small holder agriculture through

biological nitrogen fixation (BNF) in soybean

E. Musimwa and O. Mukoko.

Estimates of $\mathrm{N}_{2}$ fixation in cowpea grown in farmers' fields

in the upper west region of Ghana

J. B. Naab, S. B. M. Chimphango and F. D. Dakora . . 
Integrating $\mathrm{N}_{2}$-fixing legumes, soils, and livelihoods in southern Africa: A consortium approach

P. Mapfumo

Distribution of promiscuous soyabean rhizobia in some Zimbabwean soils J. S. Mukutiri, S. Mpepereki and F. Makonese . . . . . . . . . . . . . . . . . 113

Ecophysiological studies of legumes in Botswana: Types of bacterial strains from root nodules of cowpea (Vigna unguiculata L. Walp.) and an assessment of the symbiotic status of grain legumes using ${ }^{15} \mathrm{~N}$ natural abundance F. Pule-Meulenberg, T. Krasova-Wade and F. D. Dakora . . . . . . . . . . . . . 115

Symbiotic N nutrition and yield of cowpea genotypes under different plant densities and cropping systems J. H. J. R. Makoi, S. B. M. Chimphango and F. D. Dakora . . . . . . . . . . . . . . 117

The diversity of root nodule bacteria associated with Lebeckia species in South Africa

F. L. Phalane, E. T. Steenkamp, I. J. Law and W. F. Botha

Rhizobial diversity associated with South African legumes

M. A. Pérez-Fernández, A. J. Valentine and S. Muñoz García-Mauriño

Diversity and competitiveness of rhizobia of the legume tree Acacia nilotica in Senegal

R. T. Samba, M. Neyra, D. Francis, S. Sylla and I. Ndoye. .

Effects of rock phosphate on indigenous rhizobia associated with Sesbania sesban

O. Sacko, R. T. Samba, I. Yattara, N. Faye, F. do Rego, T. Diop,

M. Neyra and M. Gueye . . . . . . . . . . . . . . . . . . . . . . . . . . . . . . 125

Effect of added fertilizers on $\mathrm{N}_{2}$ fixation and plant performance of shrubby legumes

M. A. Pérez-Fernández, A. J. Valentine, E. Calvo, S. Muñoz and C. Vicente

Genetic diversity of Acacia seyal del. rhizobial populations indigenous

to Senegalese soils in relation to salinity and $\mathrm{pH}$ of the sampling sites

D. Diouf, R. Samba-Mbaye, D. Lesueur, A. Bâ, B. Dreyfus,

$P$. de Lajudie and M. Neyra .

Potential effects of elevated UV-B radiation on $\mathrm{N}_{2}$-fixing legumes in agricultural systems

S. B. M. Chimphango, C. F. Musil and F. D. Dakora . 
Arbuscular mycorrhizal colonization and nodulation improve flooding tolerance in Pterocarpus officinalis jacq. seedlings

L. Fougnies, S. Renciot, F. Muller, C. Plenchette, Y. Prin, S. M. de Faria,

J. M. Bouvet, S. Sylla, B. Dreyfus, I. Ndoye and A. Bâ. .

Mycorrhizal colonization improves growth and nutrition of an invasive legume in a Mediterranean ecosystem

A. J. Valentine, M. R. Le Roux and M. A. Pérez-Fernández .

Nutritional and photosynthetic performance of invasive and indigenous legumes in a Mediterranean ecosystem

A. J. Valentine, M. A. Pérez-Fernández, G. Shanks and P. E. Mortimer . .

Ecology and phytochemical analysis of the medicinal legume, Sutherlandia

frutescens (L.)R. Br., at two locations

Q. Johnson, A. J. Valentine and M. A. Pérez-Fernández

Improving chickpea inoculation in the northern cropping region of Australia

A. McInnes, C. Douglas, J. Thies, J. Slattery, P. Thompson and K. McCosker . . . . . 141

Optimizing chickpea nodulation for nitrogen fixation and yield

in north-western New South Wales, Australia

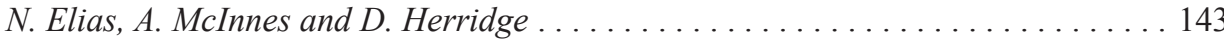

Investigating nitrogen fixation in the Medicago-Sinorhizobium symbiosis

J. J. Terpolilli, R. P. Tiwari, M. J. Dilworth, G. W. O'Hara and J. G. Howieson . . . 145

Non-symbiotic nitrogen fixation in soil, litter, and phyllosphere

in dry Chaco forest of Argentina

A. Abril and L. Noe .

Inoculation and competitiveness of a Bradyrhizobium sp. strain in soils

containing indigenous rhizobia

C. Bonfiglio, P. Bogino and W. Giordano

Diverse role of diazotrophs in the rhizosphere

F. Y. Hafeez, S. Hameed, M. S. Mirza, F. Mubeen, S. Yasmin,

A. Aslam, M. Gull and K. A. Malik.

Role of nature's fertility partners with crop protectants

for sustainable agriculture

F. Mubeen, A. Aslam, V. Radl, M. Schloter, K. A. Malik and F. Y. Hafeez . 
Characterization of bradyrhizobia isolated from root nodules of Cytisus triflorus in the Rif Occidental of Morocco

R. Chahboune, M. R. El Akhal, A. Arakrak, M. Bakkali, A. Laglaoui,

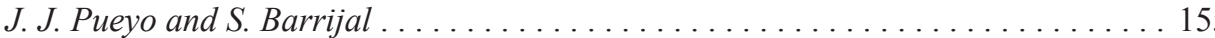

Diversity of rhizobia isolated from nodules of peanut (Arachis hypogaea L.)

in Morocco

M. R. El Akhal, A. Rincón, F. Arenal, A. Laglaoui, N. El Mourabit,

J. J. Pueyo and S. Barrijal.

Diversity of rhizobia that nodulate Colutea arborescens isolated

from different soils of Morocco

O. Mohamed, H. Benata, H. Abdelmoumen, M. Amar and M. M. El Idrissi . . . . . . . 159

Diversity of rhizobia that nodulate the two mediterranean legumes,

Adenocarpus decorticans and Retama menosperma

H. Abdelmoumen, M. Neyra, R. T. Samba and M. M. El Idrissi .

Response of common bean and fababean to effective nodulation

in salt- and drought-stressed areas around the Nile delta

Y. Yanni, M. Zidan, R. Rizk, A. Mehesen, F. A. El-Fattah and H. Hamisa . . . . . . . . 163

\section{Section 2. Nodule Organogenesis and Plant Genomics}

A. Host Response to Invasion

Nod-factor perception in Medicago truncatula

J. Cullimore, B. Lefebvre, J. F. Arrighi, C. Gough, A. Barre, J. J. Bono,

P. Rougé, E. Samain, H. Driguez, A. Imberty, A. Untergasser, R. Geurts,

T. W. J. Gadella, Jr., J. Cañada and J. Jimenez-Barbero . . . . . . . . . . . . . . . . . 167

Nodulation control in legumes

P. M. Gresshoff, A. Indrasumunar, S. Nontachaiyapoom, M. Kinkema,

Y.-H. Lin, Q. Jiang, D. X. Li, A. Miyahara, C. Nguyen, D. Buzas,

B. Biswas, P. K. Chan, P. Scott, T. Hirani, M. Miyagi, M. Djordjevic,

B. J. Carroll, A. Men and A. Kereszt . . . . . . . . . . . . . . . . . . . . . . . . . 173

Bacteroid differentiation is linked to evolution of a high diversity of secreted peptides in the host plant

E. Kondorosi, B. Alunni, Z. Kevei, N. Maunoury, W. van de Velde, M. R. Nieto, P. Mergaert and A. Kondorosi 
Functional genomics of soybean root-hair infection

G. Stacey, L. Brechenmacher, M. Libault and S. Sachdev .

Regulation of nodule organogenesis by auxin transport and flavonoids

G. E. van Noorden, A. P. Wasson, F. I. Pellerone, J. Prayitno,

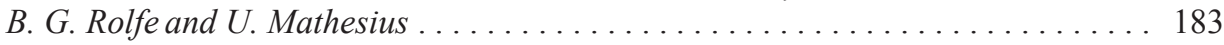

Legume AGP-extensins in Rhizobium infection

N. Brewin, A. Khodorenko, V. E. Tsyganov, A. Y. Borisov, I. A. Tikhonovich

and E. Rathbun

Glycoside hydrolases from legumes and rhizobia at the symbiotic interface

C. Staehelin, Y.-J. Dong, Y. Tian, J.-S. Xiong and Z.-P. Xie

Transcript profiling of nodule senescence in Medicago truncatula delineates distinct phases and mechanisms

S. Goormachtig, J. C. P. Guerra, K. D'haeseleer, W. Van de Velde,

A. De Keyser and M. Holsters .

Comparison of leaf growth of hypernodulation soybean mutants,

NOD1-3, NOD2-4 and NOD3-7, with their parent cv. Williams

S. Ito, N. Ohtake, K. Sueyoshi and T. Ohyama .

Actinorhizal nodules and gene expression

V. Hocher, B. Péret, L. Laplaze, F. Auguy, H. Gherbi, S. Svistoonoff,

C. Franche and D. Bogusz . . . . . . . . . . . . . . . . . . . . . . . 195

B. Nodule Physiology and Genetics

Characterization of glutathione S-transferases from legume root nodules

D. A. Dalton, J. Scott, L. Jelinek and Z. Turner . . . . . . . . . . . . . . . . . 203

Overexpression of flavodoxin in alfalfa nodules leads to delayed senescence and high starch accumulation

T. C. de la Peña, F. J. Redondo, M. M. Lucas and J. J. Pueyo . . . . . . . . . . . . . 205

Effects of the overexpression of a soybean cytosolic glutamine

synthetase gene (GS15) linked to organ-specific promotors

on growth and nitrogen accumulation of pea plants

J. K. Vessey, H. Fei, S. Chaillou, B. Hirel, P. Polowick and J. D. Mahon . . . . . . . 207

Role of PEPc isoforms in phosphate-deficient nodules

A. Kleinert, M. Venter, J. Kossmann and A. J. Valentine . 
Over-expression of the class 1 hemoglobin gene contributes

to symbiotic nitrogen fixation

T. Uchiumi, F. Sasakura, M. Nagata, Y. Shimoda, A. Suzuki,

K. Kucho, T. Sano, S. Higashi and M. Abe . . . . . . . . . . . . . . . . . . . 213

C. Plant Genomics and Transcriptomics

Structural and comparative genome analysis of Lotus japonicus

S. Sato, T. Kaneko, Y. Nakamura, E. Asamizu, T. Kato and S. Tabata

Novel symbiotic regulatory genes identified by transcriptomics

in Medicago truncatula

J.-P. Combier, T. Vernie, S. Moreau, T. Ott, L. Godiard,

A. Niebel and P. Gamas ... . . . . . . . . . . . . . . . . . . . . . . . . . 221

Genome synteny of pea and model legumes: From mutation through

genetic mapping to the genes

V. A. Zhukov, A. Y. Borisov, E. V. Kuznetsova, L. H. Madsen,

M. D. Moffet, E. S. Ovchinnikova, A. G. Pinaev, S. Radutoiu,

S. M. Rozov, T. S. Rychagova, O. Y. Shtark, V. E. Tsyganov,

V. A. Voroshilova, J. Stougaard, N. F. Weeden and I. A. Tikhonovich .

The Medicago truncatula lin mutant: Caught by map-based cloning,

characterised by transcriptomics

G. Endre, E. Kiss, A. Borbola, H. Tiricz, A. Lozsa, B. Olah,

K. Kuppusamy, N. Sharopova and K. A. VandenBosch . . .

Proteomic analysis of secreted proteins of Glycine max and Medicago spp.

M. A. Djordjevic, M. Oakes, L. Kusumawati, C. Hocart, C. McKinlay,

C.-H. Hwang, D. Li and P. M. Gresshoff

D. Bacterial Partner

Proteomic and transcriptomic approaches to study global genome expression in Rhizobium etli and Sinorhizobium meliloti

S. Encarnación, E. Salazar, G. Martínez, M. Hernández, A. Reyes, M. del C. Vargas, S. Contreras, M. Elizalde, R. Noguez,

$N$. Meneses, O. Bueno, R. Sánchez, Y. Mora and J. Mora

Control and action of the transcriptional regulator TtsI of Rhizobium sp. NGR234

R. Wassem, K. Kambara, H. Kobayashi, W. J. Broughton and W. J. Deakin . . 
Symbiotic roles and transcriptional analysis of the type III secretion system in Mesorhizobium loti

S. Okazaki, S. Okabe, S. Zehner, M. Göttfert and K. Saeki

Toxin-antitoxin modules and symbiosis

M. Bodogai, Sz. Ferenczi, S. P. Miclea, P. Papp and I. Dusha .

Comparative analysis of ArgC protein expression in Rhizobium species

M. del C. Vargas, M. A. Villalobos, R. Díaz, M. A. Flores, S. Contreras,

S. Encarnación, Y. Mora, M. F. Dunn, L. Girard and J. Mora . . . . . . . . . . . . . 239

Genistein-dependent regulatory circuits in Bradyrhizobium japonicum

K. Lang, A. Lindemann, F. Hauser, H. Hennecke, S. Zehner and M. Göttfert . . . . . 241

Rhizobium leguminosarum modification of its lipopoly-saccharide during symbiotic bacteroid development

E. L. Kannenberg, T. Härtner, L. S. Forsberg and R. W. Carlson

Altered formations of special eubacterial membrane lipids affect

bacterial interactions with eukaryotic hosts

O. Geiger, I. M. López-Lara and C. Sohlenkamp

Rhizobium leguminosarum bv viciae strain LC-31: Analysis of novel bacteriocin and ACC deaminase gene(s)

F. Y. Hafeez, Z. Hassan, F. Naeem, A. Bashir, A. Kiran,

S. A. Khan and K. A. Malik.

Infection of legumes by beta-rhizobia

E. K. James, G. N. Elliott, W.-M. Chen, C. Bontemps, J. P. W. Young,

S. M. de Faria, F. B. dos Reis, Jr., M. F. Simon, E. Gross, M. F. Loureiro,

V. M. Reis, L. Perin, R. M. Boddey, C. E. Hughes, L. Moulin,

A. R. Prescott and J. I. Sprent.

In search of beta-rhizobia: Exploring the symbionts of mimosa in Brazil

C. Bontemps, G. Elliott, E. K. James, J. I. Sprent, M. Simon, C. Hughes

and J. P. W. Young

Effect of phosphoglycerate mutase deficiency on the free-living and symbiotic life of Burkholderia phymatum S.-Y. Sheu, D.-S. Sheu, C.-Z. Ke, K.-Y. Lin, J.-H. Chou, J. Prell, E. K. James, G. N. Elliott, J. I. Sprent and W.-M. Chen . 
Living large: Elucidation of the Frankia EAN1pec genome sequence shows gene expansion and metabolic versatility

L. S. Tisa, D. R. Benson, G. B. Smejkal, P. Lapierre, J. P. Gogarten,

P. Normand, M. P. Francino and P. Richardson.

E. Summary Presentations

Phosphate-dependent gene expression in free-living and symbiotic Sinorhizobium meliloti

R. Zaheer, Z. Yuan, R. Morton and T. M. Finan . .

Characterization of Bradyrhizobium elkanii type III secretion system

S. Okazaki, S. Zehner, K. Lang and M. Göttfert. . .

Search for a nodulation gene inducer for Mesorhizobium loti secreted from roots of Lotus corniculatus

K. Kojima, T. Yokoyama, M. Itakura, K. Minamisawa and Y. Arima . . . . . . . . 263

Identification of BetX, a periplasmic protein involved in binding and uptake of proline betaine and glycine betaine in Sinorhizobium meliloti B. Sagot, G. Alloing, D. Hérouart, D. Le Rudulier and L. Dupont . .

$\mathrm{H}_{2} \mathrm{O}_{2}$ is required for optimal infection-thread formation during Sinorhizobium meliloti symbiosis

A. Jamet, K. Mandon, A. Chéron, C. Coste-Maehrel, D. Le Rudulier,

F. Barloy-Hubler, A. Puppo and D. Hérouart .

Molecular approaches for the characterization of Bradyrhizobium strains

S. B. Campos, A. Giongo, A. Ambrosini, A. Beneduzi, N. Cobalchini,

M. H. Bodanese-Zanettini and L. M. P. Passaglia . .

Genotypic and phenotypic variations among rhizobia nodulating red clover in soils of northern Scandinavia

S. Duodu, G. Carlsson, K. Huss-Danell and M. M. Svenning

$\mathrm{NH}_{4}{ }^{+}$nutrition affects the photosynthetic and respiratory $\mathrm{C}$ sinks in the dual symbiosis of a mycorrhizal legume

P. E. Mortimer, M. A. Pérez-Fernández and A. J. Valentine..

The effect of $\mathrm{P}$ nutrition on AM colonization, nodule development and the $\mathrm{N}$ and $\mathrm{C}$ metabolism of Phaseolus vulgaris P. E. Mortimer, M. A. Pérez-Fernández and A. J. Valentine. 
Effects of $\mathrm{Al}^{3+}$ toxicity on photosynthetic and respiratory responses of Phaseolus vulgaris under P deficiency

R. Hugo, M. A. Perez-Fernandez and A. J. Valentine. .

Assimilate allocation between the organic acid and amino acid pools in Lupinus angustifolius under P stress

M. R. Le Roux, S. Khan and A. J. Valentine

African species belonging to the tribe Psoraleeae produce ureides, a symbiotic trait characteristic of the Phaseoleae

S. Kanu, S. B. Chimpango, J. Sprent and F. D. Dakora . .

New look at old root-nodule bacteria: Molecular techniques uncover novel isolates

J. K. Ardley, R. J. Yates, K. Nandasena, W. G. Reeve, I. J. Law,

L. Brau, G. W. O'Hara and J. G. Howieson. .

Characterization of a novel non-rhizobial symbiont from Cicer arietinum

A. Aslam, K. A. Malik and F. Y. Hafeez . . . . . . . . . . . . . . . . . . 285

Burkholderia tuberum effectively nodulates Cyclopia spp., but not Aspalathus spp.

G. N. Elliott, W.-M. Chen, C. Bontemps, F. D. Dakora,

J. P. W. Young, J. I. Sprent and E. K. James

Endosymbiosis formation between a nitrogen-fixing mix of bacteria

(Xanthomonas sp. + Arthrobacter sp.) and wheat root cells

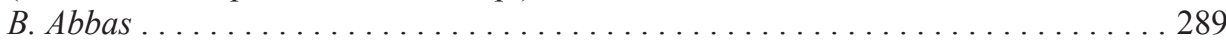

\section{Section 3. Microbiology of Nitrogen Fixation}

A. Genomics, Phylogeny, and Evolution

Integrating Sinorhizobium meliloti genomics: An expression library of the genome

A. Cowie, J. Cheng, B. Poduska, A. MacLean, R. Zaheer,

R. Morton and T. Finan

Fll genome seqence of Azotobacter vinelandii: Preliminary analysis

C. Kennedy, D. R. Dean, B. Goodner, B. Goldman, J. Setubal,

S. Slater and D. Wood . . . . . . . . . . . . . . . . . . . . . . . . . . . . 297 
Transcriptional profile of Bradyrhizobium elkanii SEMIA 587

in symbiosis with soybean (Glycine max L. Merrill) analyzed

by DNA microarray

J. Marcondes, M. Cantão, L. M. C. Alves and E. G. M. Lemos

Chronos, Chairos, and co-evolution in Rhizobium-legume symbioses

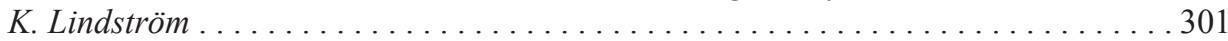

Genomics and evolution of bacteria: Nodulation, nitrogen fixation

and the rest of the accessory genome

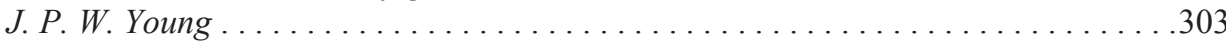

Evolution of functional diversity in nitrogenase homologs

R. E. Blankenship, J. Raymond, C. Staples and B. Mukhopadhyay . . . . . . . . . 305

B. Rhizoshpere Associations

Diversity of nitrogen fixing bacterial community assessed

by molecular and microbiological techniques

L. F. W. Roesch, R. A. Soares, G. Zanatta, F. A. de O. Camargo

and L. M. P. Passaglia.

Quorum sensing in root-associated and endophytic diazotrophs

M. Schmid, M. Rothballer, B. Hai, A. Fekete, X. Li, M. Engelmann,

M. Frommberger, P. Schmitt-Kopplin and A. Hartmann

Characterization of $\operatorname{chs}$, a new gene controlling the chemotactic

response in Azospirillum brasilense $\mathrm{Sp} 7$

R. Carreño-Lopez, A. Sánchez, N. Camargo, C. Elmerich and B. E. Baca . . . . . . . 317

Exopolysaccharide production and cell aggregation

in Azospirillum brasilense

A. Valverde, S. Castro-Sowinski, A. Lerner, S. Fibach,

O. Matan, S. Burdman and Y. Okon ..

Gluconacetobacter diazotrophicus PAL5 strain: Selection

and characterization of mutants deficient in nitrogen-fixation ability

H. V. Guedes, L. F. M. Rouws, A. L. M. Oliveira, J. L. Simões-Araújo,

K. R. S. Teixeira and J. I. Baldani 
The role of the Nif proteins in nitrogenase maturation

L. M. Rubio, J. A. Hernández, B. Soboh, D. Zhao, R. Y. Igarashi,

L. Curatti and P. W. Ludden.

NifB-dependent "in vitro" synthesis of the iron-molybdenum cofactor of nitrogenase

L. Curatti, P. W. Ludden and L. M. Rubio

Azotobacter vinelandii nitrogenase MoFe protein: Pre-steady state

spectroscopic studies of the metal cofactors

W. E. Newton, K. Fisher, B. H. Huynh, D. E. Edmondson, P. Tavares,

A. S. Pereira and D. J. Lowe .

The role of the iron protein-nucleotide interaction and conformational change

in nitrogenase catalysis

J. W. Peters, R. Sarma, D. W. Mulder, H. Tsuruta, R. K. Szilagyi

and L. C. Seefeldt .

The mechanistic basis of nif gene activation

S. Wigneshweraraj, P. Burrows, D. Bose, W. Cannon, N. Joly, M. Rappas,

J. Schumacher, X. Zhang and M. Buck.

Architecture of $\sigma^{54}$-dependent promoters: Interplay between CRP-cAMP and $\mathrm{P}_{\mathrm{II}}-\mathrm{NTR}$ systems forms a novel regulatory network between carbon metabolism and nitrogen assimilation in Escherichia coli Y.-P. Wang .

D. Photosynthetic Nitrogen Fixers

Signals in the regulation of nitrogen fixation and ammonium assimilation in the photosynthetic bacterium Rhodospirillum rubrum A. Jonsson, P. Teixeira and S. Nordlund . .

Defining the roles $\mathrm{P}_{\mathrm{II}}$ and $\mathrm{AmtB}$ proteins in the $\mathrm{NH}_{4}{ }^{+}$-induced post-translational control of nitrogenase activity

L. F. Huergo, M. Merrick, L. S. Chubatsu, F. O. Pedrosa,

M. B. Steffens and E. M. Souza.

Metabolic regulation of nitrogen fixation in Rhodospirillum rubrum and evidence for an energy-dependent ammonium transport system H. Wang, A. Norén and S. Nordlund. 
Membrane sequestration of $\mathrm{P}_{\mathrm{II}}$ proteins and nitrogenase regulation in Rhodobacter capsulatus

Molybdenum regulation of nitrogen fixation and Mo-metabolism in Rhodobacter capsulatus

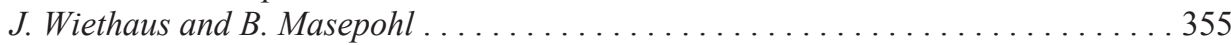

Hydrogen production by cyanobacteria as a potential tool in energy-conversion programmes H. Bothe, G. Boison and S. Junkermann .

Regulatory interactions involved in nitrogen signalling in cyanobacteria: Partner swapping and role of PipX-P $\mathrm{P}_{\mathrm{II}}$ complexes in Synechococcus sp. PCC 7942

Intercellular transfer of nitrogen in heterocyst-forming cyanobacteria

Genomics and systems biology analysis of Cyanothece sp. ATCC 51142, a unicellular, diazotrophic cyanobacterium with robust metabolic rhythms E. A. Welsh, M. Liberton, J. Stockel, H. B. Pakrasi, H. Min,

J. Toepel and L. A. Sherman . . . . . . . . . . . . . . . . . . . . . . . . 365

E. Summary Presentations

Sinorhizobium arboris genes are differentially expressed under salt stress P. Penttinen, Z. Terefework, L. Paulin, P. Auvinen, D. Greco and K. Lindström . . . 371

Thiol-redox potential in melanin production and nitrogen fixation by Sinorhizobium meliloti

S. Castro-Sowinski, O. Matan, L. Star and Y. Okon

Use of chimeric proteins to investigate the role of the Gaf domain of Herbaspirillum seropedicae NifA in the response to fixed nitrogen R. A. Monteiro, R. Dixon, R. Little, M. A. S. Oliveira, R. Wassem, M. B. R. Steffens, L. S. Chubatsu, L. U. Rigo, F. O. Pedrosa and E. M. Souza . . . . 375

Molecular characterization of symbiotic bacteria associated with the pasture legume Ornithopus sp. native to Portugal C. Vicente, M. A. Pérez-Fernández, R. Costa, G. Pereira, N. Simões and M. Tavares-de-Sousa . . 
Siderophore genes in Gram positive and Gram negative nitrogen-fixing bacteria

A. Giongo, A. Beneduzi, A. Ambrosini, R. Farina, P. B. Costa,

S. B. Campos, M. H. Bodanese-Zanettini and L. M. P. Passaglia . . . . . . . . . . . 379

Genomics and genetic transformation in the unicellular diazotrophic

cyanobacterium Cyanothece sp. ATCC 51142

H. Min, E. A. Welsh, H. B. Pakrasi and L. A. Sherman

SipA, a novel regulator of the photosynthesis-related sensor histidine kinase, NblS

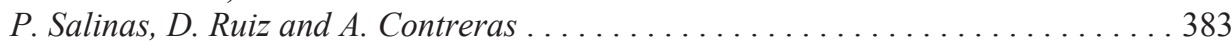

Author Index 


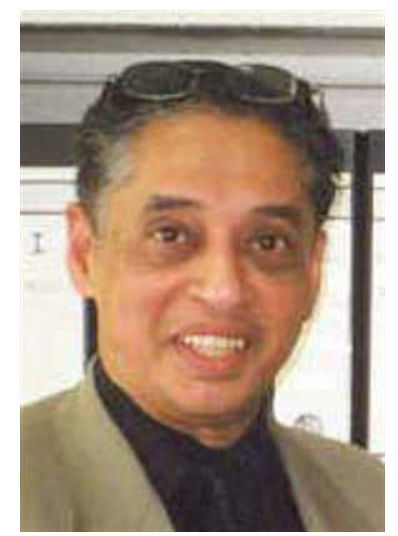

(Photo: ASM source)

\section{Edgar DaSilva}

(1941-2007)

This volume is dedicated to the memory of Edgar DaSilva, former Director of the Division of Life Sciences at UNESCO, in recognition of his long-term interest in biological nitrogen fixation research. Edgar joined UNESCO in 1974 and was responsible for the life-sciences programs. His name is associated with the UNESCO Microbiological Resource Centers (MIRCEN) program, which was initiated in 1975 in partnership with the United Nations Environment Program (UNEP), and the United Nations Development Program (UNDP). He was involved in the implementation of five Biotechnology Education and Training Centres (BETCEN), one on each continent. The MIRCENs and BETCENs proved to be very successful and offered training to young scientists from developing countries as well as opportunities for international cooperation. He developed fellowship programs for research and training both within UNESCO's biotechnology program and also with partners like the American Society for Microbiology (ASM) and the International Union of Microbiological Societies (IUMS). One of his ambitions was that research carried out in developing countries should be recognized and given the necessary support. To this end, in 1985, he was instrumental in the launch of a journal, which is now published by Springer as "World Journal of Microbiology and Biotechnology". Edgar wrote numerous articles and reviews for many journals, especially those in the fields of microbiology and biotechnology. After his retirement in 2001, he continued his visits to many countries and also served as co-editor of the "Biotechnology" theme for the UNESCOsponsored "Encyclopaedia for Life Support Systems". We thank Lucy Hoareau, Division of Basic and Engineering Sciences at UNESCO, for supplying this dedication. 


\section{Preface}

Poverty is a severe problem in Africa, Asia, South America and even in pockets of the developed world. Addressing poverty alleviation via the expanded use of biological nitrogen fixation in agriculture was the theme of the 15th International Congress on Nitrogen Fixation. Because nitrogen-fixation research is multidisciplinary, exploiting its benefits for agriculture and environmental protection has continued to attract research by diverse groups of scientists, including chemists, biochemists, plant physiologists, evolutionary biologists, ecologists, agricultural scientists, extension agents, and inoculant producers.

The 15th International Congress on Nitrogen Fixation was held jointly with the 12th International Conference of the African Association for Biological Nitrogen Fixation. This joint Congress was hosted in South Africa at the Cape Town International Convention Centre, 21-26 January 2007, and was attended by about 200 registered participants from 41 countries world-wide. During the Congress, some 100 oral and approximately 80 poster papers were presented. The wide range of topics covered and the theme of the Congress justifies this book's title, Nitrogen Fixation: Applications to Poverty Alleviation.

Crop yields depend on many factors, but primarily on three major inputs; the capture of the Sun's light energy as chemical energy through photosynthesis, a source of water, and on the availability of a fixed-nitrogen (either mineral or organic) source. This Congress dealt with the last of these three major inputs. An enormous reservoir of nitrogen resides in the atmosphere as nitrogen $\left(\mathrm{N}_{2}\right)$ gas, however, this atmospheric nitrogen is not directly usable. It only becomes available to the biosphere through biological nitrogen fixation (BNF), a process that only the simplest microorganisms have developed. Through associations with these nitrogen-fixing microorganisms, plants can, in turn, derive a significant proportion of their fixed-nitrogen requirement for growth from BNF. The most agriculturally important associations are those of legume crops (for example, soybeans, peas, and feed legumes, like alfalfa and clover) with Rhizobium bacteria, where a tight symbiotic relationship occurs within a specially developed organ, the nodule, usually on the roots of the plants. An ecologically significant association involves Frankia microbes with trees and shrubs, which help reclaim devastated soils, and through inter-cropping can enhance the growth of valuable lumber-producing trees. Other associations include cyanobacteria with plants and trees as well as the more informal associative and endophytic associations of microorganisms with grasses, most particularly with sugarcane, where possibly all of its fixed-nitrogen requirement can be supplied by BNF. These examples clearly illustrate why BNF is a key metabolic process for food production and the maintenance of life on Earth. 
The Congress theme, the application of BNF to sustainable agriculture, poverty alleviation, and environmental concerns, was well covered and included the introduction of nitrogen-fixing legumes into local small holdings, appropriate use of both soil and water, the use of indigenous soil microbes to provide $\mathrm{N}$ and $\mathrm{P}$, and good agricultural practices generally. In addition, the basic sciences that underpin these more applied aspects were also well represented through presentations and progress reports, among others, on the fundamentals of nitrogen fixation (including a nitrogenase - the enzyme responsible for the chemical conversion of $\mathrm{N}_{2}$ gas to ammonia - that can fix $\mathrm{N}_{2}$ at $92^{\circ} \mathrm{C}$ !), plant breeding, plant and microbial molecular biology, legume-Rhizobium genetics, genomics, gene expression, evolution of symbioses, and nodulation physiology, stress responses, bioremediation, and forestry.

Sustainable agriculture not only depends on appropriate agricultural practices but, to maintain high yields, it requires the use of plant cultivars that respond to environmental constraints. In addition to classical plant-breeding technology, the modern-day engineering of high-performance crops and symbiotic associations can now access and use the incredible insight acquired through plant and bacterial genomics. Both topics were well represented in the Congress. Indeed, refined gene-sequence maps of the model legumes, Lotus japonicus and Medicago truncatula, have led to exciting genomic work in other legumes. On the microbial side, research on Sinorhizobium meliloti and Mesorhizobium loti as well as the broad host range Rhizobium NGR234 has reached the post-genomics era. The recent and rapid progress made in sequencing the genomes of Azotobacter vinelandii, Azospirillum brasilense, Herbaspirillum seropedicae, Azorhizobium caulinodans, Gluconactetobacter diazotrophicus and Frankia was also reported.

Moreover, there were reports of photosynthetic bradyrhizobia that lack the nodAC genes, which are necessary for Nod-factor biosynthesis and, therefore, for initiation of symbiosis. This discovery opens new opportunities for research in the area of plantmicrobe signaling during the early stages of symbiotic establishment. New exciting data showed that members of the $\beta$-proteobacteria (only recently recognized as microsymbionts), isolated from Mimosoideae can infect and fix $\mathrm{N}_{2}$ in Papillionoideae. All this plus a cyanobacterium that anticipates sunrise each morning!

Taken together, the excellent technical presentations and the lively discussions that ensued, both during and after the oral and poster sessions, are clear indicators of the success of the Congress. We hope that this volume will serve as a living reminder of those sweet moments in Cape Town. On a sad note, during the preparation of these Proceedings, we learned of the untimely death of Edgar DaSilva, who was an avid supporter of biological nitrogen-fixation research. We feel it only appropriate to dedicate these Proceedings to his memory.

Finally, we wish to thank all the individuals who helped to organize this Congress and all those who gave their support, including Ms. Helen Zille, the Mayor of Cape Town, Mr. Ben Durham, who represented the RSA Department of Science and 
Technology, Professor Wieland Gevers, the CEO of the Academy of Sciences of South Africa, and Dr. Ibrahima Ndoye of the AABNF. We also thank the sponsoring organizations, listed elsewhere, without whose financial support the Congress would not have been possible. We especially thank Elizabeth Danckwerts (and her Mum) for their commitment and tireless effort in organizing the Congress. We sincerely appreciate Vicki Newton for her hard work, dedication, and guidance towards getting these Proceedings published. Lastly, we thank Edwina Felix for her voluntary service to the Congress and all the postgraduate students who assisted during the Congress. All protocol observed!

Felix Dakora

Samson Chimphango

Alex Valentine Claudine Elmerich William E. Newton

Cape Town

December 31, 2007 